\title{
Proteomic analysis of ERK1/2-mediated human sickle red blood cell membrane protein phosphorylation
}

Erik J Soderblom¹, J Will Thompson', Evan A Schwartz², Edward Chiou², Laura G Dubois ${ }^{1}$, M Arthur Moseley and Rahima Zennadi ${ }^{2,3 *}$

\begin{abstract}
Background: In sickle cell disease (SCD), the mitogen-activated protein kinase (MAPK) ERK1/2 is constitutively active and can be inducible by agonist-stimulation only in sickle but not in normal human red blood cells (RBCs). ERK1/2 is involved in activation of ICAM-4-mediated sickle RBC adhesion to the endothelium. However, other effects of the ERK1/2 activation in sickle RBCs leading to the complex SCD pathophysiology, such as alteration of RBC hemorheology are unknown.

Results: To further characterize global ERK1/2-induced changes in membrane protein phosphorylation within human RBCs, a label-free quantitative phosphoproteomic analysis was applied to sickle and normal RBC membrane ghosts pre-treated with U0126, a specific inhibitor of MEK1/2, the upstream kinase of ERK1/2, in the presence or absence of recombinant active ERK2. Across eight unique treatment groups, 375 phosphopeptides from 155 phosphoproteins were quantified with an average technical coefficient of variation in peak intensity of $19.8 \%$. Sickle RBC treatment with U0126 decreased thirty-six phosphopeptides from twenty-one phosphoproteins involved in regulation of not only RBC shape, flexibility, cell morphology maintenance and adhesion, but also glucose and glutamate transport, CAMP production, degradation of misfolded proteins and receptor ubiquitination. Glycophorin A was the most affected protein in sickle RBCs by this ERK1/2 pathway, which contained 12 unique phosphorylated peptides, suggesting that in addition to its effect on sickle RBC adhesion, increased glycophorin A phosphorylation via the ERK1/2 pathway may also affect glycophorin A interactions with band 3, which could result in decreases in both anion transport by band 3 and band 3 trafficking. The abundance of twelve of the thirty-six phosphopeptides were subsequently increased in normal RBCs co-incubated with recombinant ERK2 and therefore represent specific MEK1/2 phospho-inhibitory targets mediated via ERK2.
\end{abstract}

Conclusions: These findings expand upon the current model for the involvement of ERK1/2 signaling in RBCs. These findings also identify additional protein targets of this pathway other than the RBC adhesion molecule ICAM- 4 and enhance the understanding of the mechanism of small molecule inhibitors of MEK/1/2/ERK $1 / 2$, which could be effective in ameliorating RBC hemorheology and adhesion, the hallmarks of SCD.

Keywords: Sickle cell disease, Mitogen-activated protein kinase ERK1/2, Red blood cell membrane, Label-free quantitation, Phosphoproteomics, Glycophorin A, Hemorheology

\footnotetext{
* Correspondence: zenna001@mc.duke.edu

${ }^{2}$ Division of Hematology and Duke Comprehensive Sickle Cell Center,

Department of Medicine, Duke University Medical Center, Durham, NC, USA

3 Duke University Medical Center, Box 2615, Durham, NC 27710, USA

Full list of author information is available at the end of the article
} 


\section{Background}

Sickle cell disease (SCD) is a hereditary blood disorder, which comprises a class of hemoglobinopathies in which a sickling variant of the $\beta$ chain of hemoglobin ( $\mathrm{HbS}$, containing $\mathrm{Hb} \beta$ glu $\left.{ }^{6} \rightarrow \mathrm{val}\right)$ is expressed. Sickle red blood cells homozygous for $\mathrm{HbS}$ (SS RBCs) are characterized by a panoply of abnormalities, including polymerization of deoxygenated $\mathrm{HbS}[1,2]$, persistent oxidative membrane damage associated with $\mathrm{HbS}$ cyclic polymerization [3], abnormal activation of membrane cation transports, cell dehydration [4], cytoskeletal dysfunction [5], and increased adhesion [6]. These alterations in SS RBCs lead to the complex pathophysiology associated with SCD that includes vaso-occlusion, chronic hemolysis and ischemic tissue damage [7].

Studies have suggested that oxidative $[8,9]$ and physiological stresses [10] are two of the prominent mechanisms leading to abnormalities in SS RBCs. These stresses are thought to be propagated through alterations in normal protein phosphorylation events within complex intracellular signaling pathways which may subsequently affect protein structural stability $[11,12]$, formation of protein-protein complexes [13,14], activation of ion transport leading to cell dehydration [15-17] and RBC adhesive function $[18,19]$. Several proteins involved in these pathways have been previously shown to be differentially tyrosine phosphorylated in SS RBCs compared to normal (AA) RBCs, including adducin, ankyrin 1, the actin binding protein dematin, and protein band 4.1, which stabilizes the spectrin-actin interaction $[14,20]$.

Recently, we have shown that extracellular signalregulated kinase (ERK1/2) is hyperactive and can be inducible in SS but not in AA RBCs, and can act downstream of the cAMP/PKA/MEK1/2 pathway [18]. ERK1/2 is a member of the large mitogen-activated protein kinase (MAPK) family of serine/threonine kinases with a known downstream target consensus motif of PX[pS/T]P [21-24]. ERK1/2 responds to stimulation by a variety of different hormones, growth factors, and insulin [18,25-27] and mediates diverse functions including modulation of proliferation, differentiation, apoptosis, migration, and cell adhesion [28-31]. Aberrations in ERK1/2 signaling have been previously reported to occur in a wide range of pathologies including cancer, diabetes, viral infection, and cardiovascular disease [32,33]. In SCD, abnormal ERK1/2 phosphorylation and subsequent activation is involved in increased phosphorylation of SS RBC adhesion molecule ICAM-4, mediating $\mathrm{RBC}$ adhesion to the endothelium, the phenotypic hallmark of this disease [18]. It is still unknown, however, which other erythrocyte membrane proteins might be affected by the ERK1/2 signaling, and whether these proteins contribute to the pathophysiology of SCD.

To further characterize global MEK1/2/ERK1/2-induced changes in protein phosphorylation within human RBCs, we employed a previously established label-free quantitative phosphoproteomics strategy to the plasma membrane ghosts of human RBCs [18,34].

\section{Results and discussion}

\section{Label-free quantitative phosphoproteomic profiling of} RBC membranes

LC-MS based quantitation of global (non-targeted) phosphorylation events directly from human RBCs in disease-affected patients has been very limited in the literature [12]. The most common analytical strategies have employed coupling two-dimensional gel electrophoresis of solubilized RBC proteins with either global ${ }^{32} \mathrm{P}$ labeling or anti-phosphotyrosine detection antibodies, followed by LC-MS/MS identification of phosphoproteins from differentially expressed protein spots [12,35]. In addition to the limited number of unique treatment conditions, which could be directly compared within a single study, these previous approaches do not allow residuespecific quantitation of phosphorylation events as initial detection in changes in phosphorylation status are measured at the protein level. This is particularly problematic for proteins containing multiple sites of phosphorylation, as each could be independently modulated by different kinases or phosphatases as a function of various stimuli. In addition, different phosphorylation sites could have different effect on protein function. Although strategies such as iTRAQ, commonly used for phosphoproteomic quantitation from non-cell culture based systems, address some of these limitations, the reagents add significant cost when performing the labeling at the quantities of total protein required for phosphoproteomic analysis.

To further characterize global MEK1/2/ERK1/2-induced changes in protein phosphorylation within human SS RBCs, a global label-free quantitative phosphoproteomic discovery analysis of SS and AA RBC plasma membrane ghosts was performed [18]. To determine specific involvement of the ERK1/2 activation in SS RBC membrane protein phosphorylation, each population of SS and AA RBCs was either treated or not treated with a potent MEK1/2 inhibitor (MEKI), U0126, which specifically inhibits ERK1/2 kinase activity. RBC membrane ghosts prepared from the resulting four populations of $\mathrm{RBCs}$, were then either subsequently co-incubated in the presence or absence of exogenous recombinant active ERK2 (Figure 1A). Proteolytically digested membrane fractions from each of these eight unique samples were then subjected to a previously described label-free quantitative phosphoproteomics workflow utilizing reproducible $\mathrm{TiO}_{2}$ phosphopeptide enrichments followed by selected ion chromatographic peak quantitation of accurate-mass retention time aligned LC-MS/MS data to allow direct quantitative comparisons to be made 


\section{A. Experimental Design}

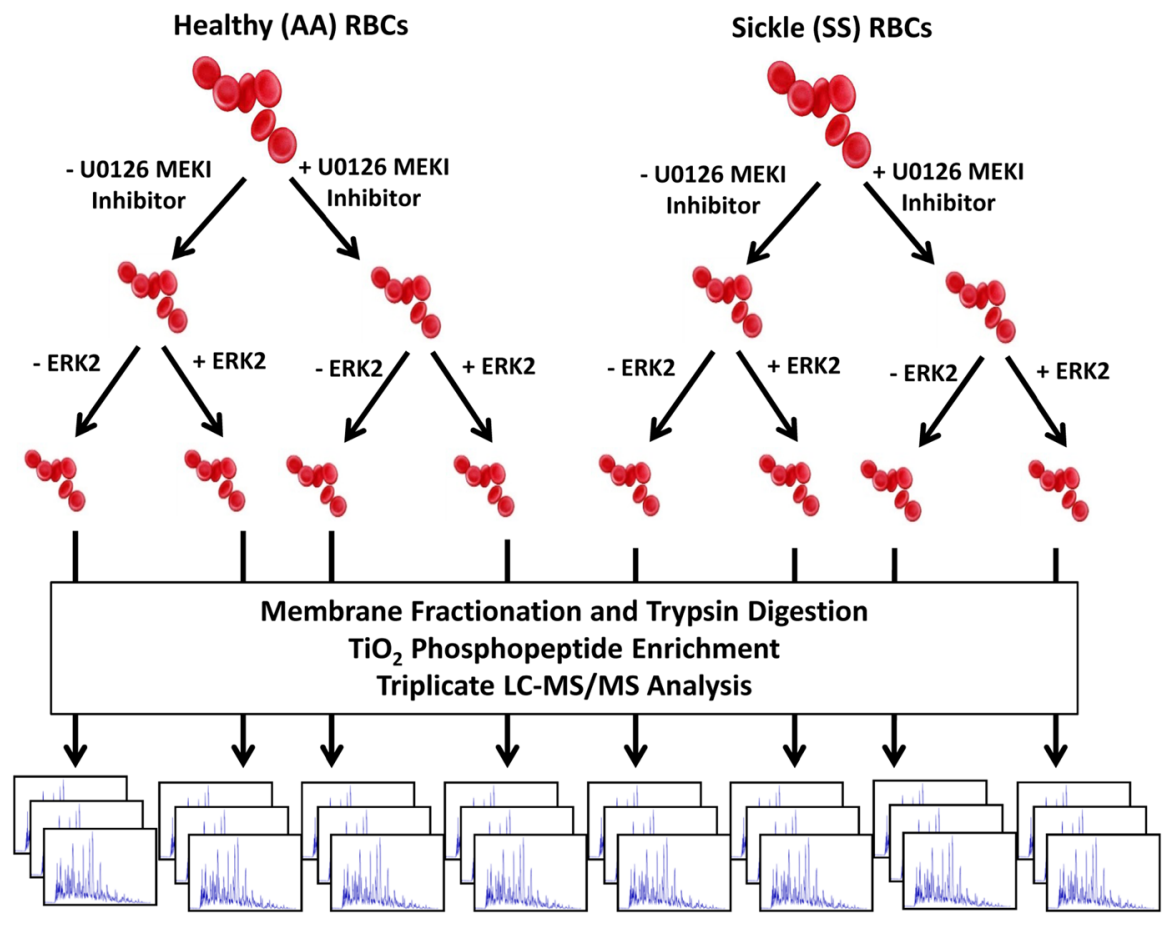

\section{B. Quantitation Strategy}

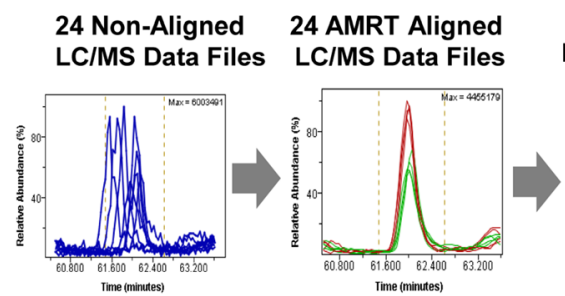

Assign Qualitative Peptide Identifications

MS/MS data
searched against
SwissProt_Human
(fwd/rev)
database and
scoring thresholds
set to a $1.0 \%$
spectral FDR.

Figure 1 Overview of the (A) experimental design and (B) analytical strategy of the label-free quantitative phosphoproteomic workflow. RBC membrane ghosts from healthy (AA) or sickle (SS) patients were proteolytically digested and then subjected to a TiO2 based phosphopeptide enrichment. Following LC-MS/MS analysis, all data files were subjected to AMRT alignment within Rosetta Elucidator and selected ion chromatograms were generated from each phosphopeptide precursor ion to measure abundance.

across all treatment groups $[18,34]$ (Figure 1B). To minimize total analysis time, each sample was analyzed in analytical triplicate by a one-dimensional LC-MS/MS analysis without any additional fractionation prior to $\mathrm{TiO}_{2}$ enrichment.

Across all samples, 375 unique phosphopeptides (527 total phosphorylated residues) corresponding to 155 phosphoproteins were identified at a peptide spectral false discovery rate of $1.0 \%$. As localization of specific phosphorylated residues is critical for defining kinase specific events, all phosphopeptides were subjected to ModLoc, a probability-based localization tool implemented within Rosetta Elucidator based on the AScore algorithm [36] (Additional file 1 Figure S1A). Approximately $74 \%$ (348) of phosphorylated residues had ModLoc scores above 15 ( $>90 \%$ probability of correct localization), and 66\% (310) had ModLoc scores above 20 ( $>99 \%$ probability of correct localization) (Additional file 2 Table). To assess the quantitative robustness of the label-free approach, the average technical coefficient of variation $(\% \mathrm{CV})$ of retention-time aligned phosphorylated peptide intensities of triplicate measurements within a treatment group were calculated (Additional file 2 Table). The mean \%CV across all 375 phosphopeptides was $19.8 \%$, with $80 \%$ of the signals having a $\% \mathrm{CVs}$ less than 27.1\% (Additional file 1 Figure S1B). The intensity of the 
phosphorylated peptide V173-[pY187]-R191 within the active site of ERK1/2 was used to assess inter-treatment group variation, including variation from $\mathrm{TiO}_{2}$ phosphopeptide enrichment, as activated ERK2 was spiked in equal amounts to four of the eight samples. The average \%CV of this phosphopeptide within any treatment group was 7.0\%, and across all ERK2 spiked samples was 18.1\% (Additional file 3 Figures S2 A\&B).

Consistent with a majority of $\mathrm{TiO}_{2}$-enrichment based global mammalian phosphoproteomic studies, 79\% (415) of the identified phosphorylated residues were localized to serines, $16 \%$ (85) to threonines, and 5\% (27) to tyrosines, with an average of 1.4 phosphorylated residues per peptide (Figure 2A). Gene ontology classification of the biological function of the 155 identified phosphoproteins indicated nearly a third of the phosphoproteins were involved in binding as their primary biological function. Sub-classification of the binding category revealed over $80 \%$ of those phosphoproteins were involved in either protein binding (51\%) or nucleotide binding (30\%) (Figure 2B). Phosphoproteins involved in ion binding consisted $12 \%$ of the total phosphoproteins (Figure 2B). As these RBC samples were prepared as membrane fractions, the large number of membranous binding proteins was not unexpected. Consistent with other RBC membrane phosphorylation studies, the phosphoproteins of SS RBC membrane ghosts with the highest number of uniquely phosphorylated peptides $(>10)$, were ankyrin-1 of the ankyrin complex, spectrin $\beta$ chain of the cytoskeleton network, and proteins of the junctional complex, including $\alpha$ - and $\beta$-adducins, dematin and protein 4.1 (Table 1). In addition, phosphoproteins with $>5$ unique
A.

Phosphorylated Residue Distribution

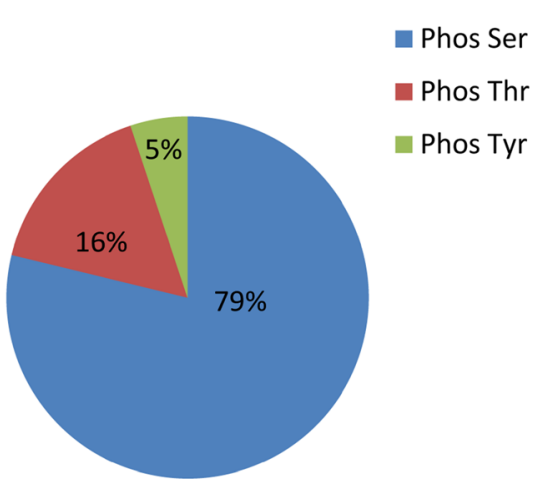
Phosphorylated residues
per Peptide

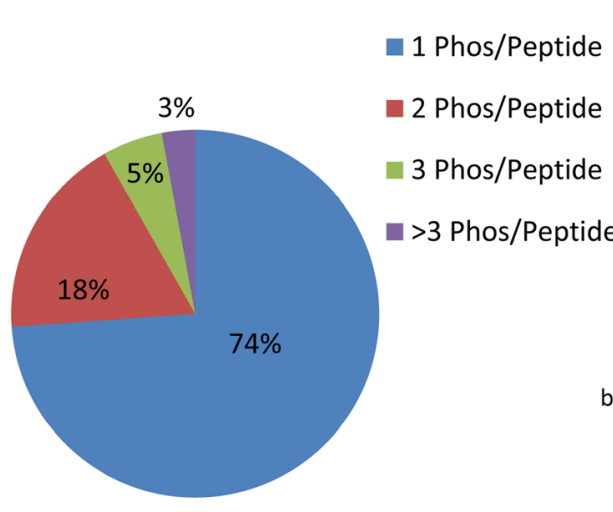

B.
Biological Function

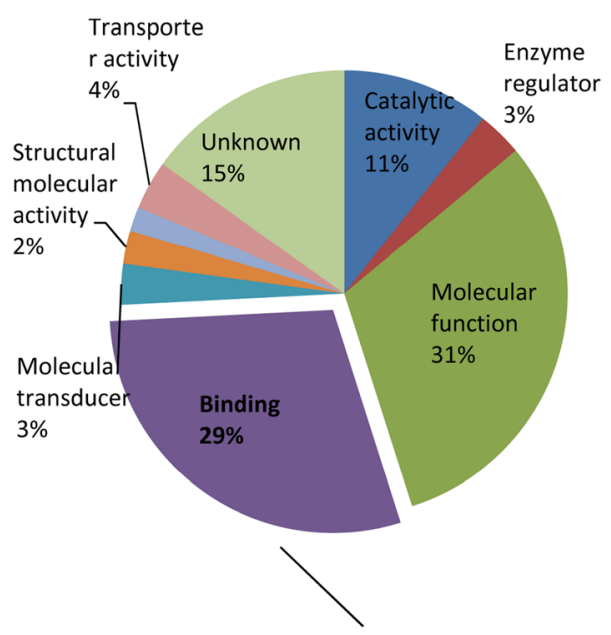

Biological Function/Binding

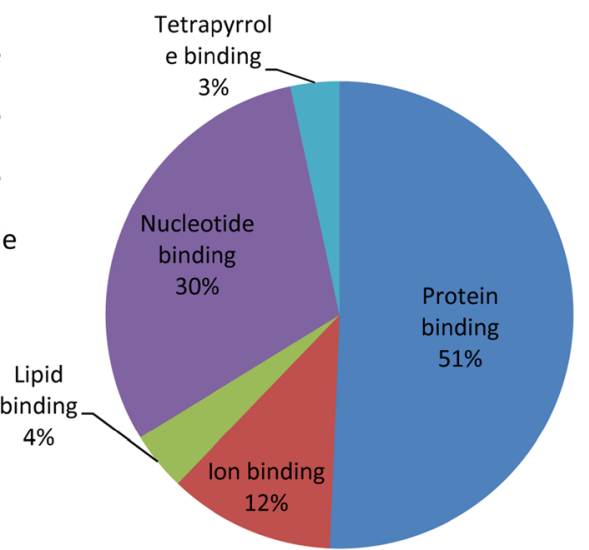

Figure 2 Phosphopeptide characteristics and phosphoprotein gene ontology classification from RBC membranes. (A) Distribution of pSer, pThr, and pTyr containing phosphopeptides (top panel) and number of phosphorylated residues per peptides (bottom panel) across all identified RBC membrane phosphopeptides. (B) NCBI Gene ontology of identified phosphoproteins implemented with Scaffold (Proteome Software). 
Table 1 Highly phosphorylated proteins identified in RBC membrane ghosts

\begin{tabular}{cccc}
\hline Protein description & $\begin{array}{c}\text { Gene } \\
\text { name }\end{array}$ & $\begin{array}{c}\text { Unique } \\
\text { phosphorylated } \\
\text { peptides }\end{array}$ & $\begin{array}{c}\text { Unique } \\
\text { phosphorylated } \\
\text { residues }\end{array}$ \\
\hline
\end{tabular}

\begin{tabular}{llcc}
\hline Ankyrin-1 & ANK1 & 33 & 23 \\
\hline Glyophorin A & GYPA & 23 & 8 \\
\hline Alpha-adducin & ADD1 & 22 & 18
\end{tabular}

\begin{tabular}{llll}
\hline Beta-adducin & ADD2 & 18 & 11 \\
\hline Protein 4.1
\end{tabular}

\begin{tabular}{llll}
\hline Protein 4.1 & EPB41 & 17 & 13 \\
\hline Dematin & EPB49 & 16 & 13
\end{tabular}

\begin{tabular}{llll}
\hline Spectrin beta chain & SPTB1 & 15 & 11 \\
\hline Band 3 anion & SLC4A1 & 14 & 7
\end{tabular}

transport protein

\begin{tabular}{llll}
\hline $\begin{array}{l}\text { Uncharacterized } \\
\text { protein LOC388588 }\end{array}$ & YA047 & 7 & 5 \\
\hline $\begin{array}{l}\text { GTPase-activating } \\
\text { protein and VPS9 }\end{array}$ & GAPVD1 & 5 & 5
\end{tabular}

domain-containing

protein 1

\begin{tabular}{llll}
\hline Lipin-2 & LPIN2 & 5 & 6 \\
\hline $\begin{array}{l}\text { Serine/threonin- } \\
\text { protein } \\
\text { kinase WNK1 }\end{array}$ & WNK1 & 5 & 6 \\
\hline
\end{tabular}

Twelve unique phosphoproteins were identified by at least five unique phosphopeptides. These included proteins of the ankyrin complex (ankyrin-1), the cytoskeleton network (spectrin $\beta$ chain) and the junctional complex involved in binding integral membrane proteins to cytoskeletal proteins ( $a$ - and $\beta$-adducins, dematin, and protein 4.1), which affect RBC shape, flexibility and adhesion, or proteins that affect anion transport, protein trafficking and adhesion (band 3 and glycophorin A), G protein activation (GTPase activating protein), lipid biosynthesis (lipin 2) and serine/threonine phosphorylation (serine/threonine protein kinase). phosphorylated peptides, known to affect RBC shape, flexibility, anion transport and protein trafficking, and adhesion, all of which contribute to the pathophysiology of SCD, were also observed (Table 1).

\section{ERK1/2 Induces atypical phosphorylation of SS RBC membrane proteins}

To assess global quantitative differences between all treatment groups, data were subjected to two-dimensional agglomerative clustering using Z-score transformed (i.e. magnitude of significance of change) individual phosphopeptide intensities (Figure 3A). This analysis revealed that the most significant differentiation (most negative Pearson correlation) across all treatment groups, was the sickle versus healthy RBC phenotype, with 201 phosphopeptides being up-regulated in SS vs AA RBCs at a foldincrease of $>1.75$. These thresholds were chosen based on an alpha value corresponding to a $95 \%$ confidence interval in a statistical powering calculation (http:// www.dssresearch.com/KnowledgeCenter/toolkitcalculators.aspx). The weight of variation from the SS to AA RBC (-0.664) was more pronounced than the addition of exogenous active ERK2 or the inhibition of MEK1/2 activity with the MEK1/2 inhibitor U0126 (Figure 3A), suggesting that in addition to MEK1/2/ERK1/2 phosphorylation cascades in the SS RBC, other cellular signaling pathway activities may be involved. Interestingly, clustering of all phosphopeptides within only the SS RBC samples revealed the strongest differentiating factor was in the presence or

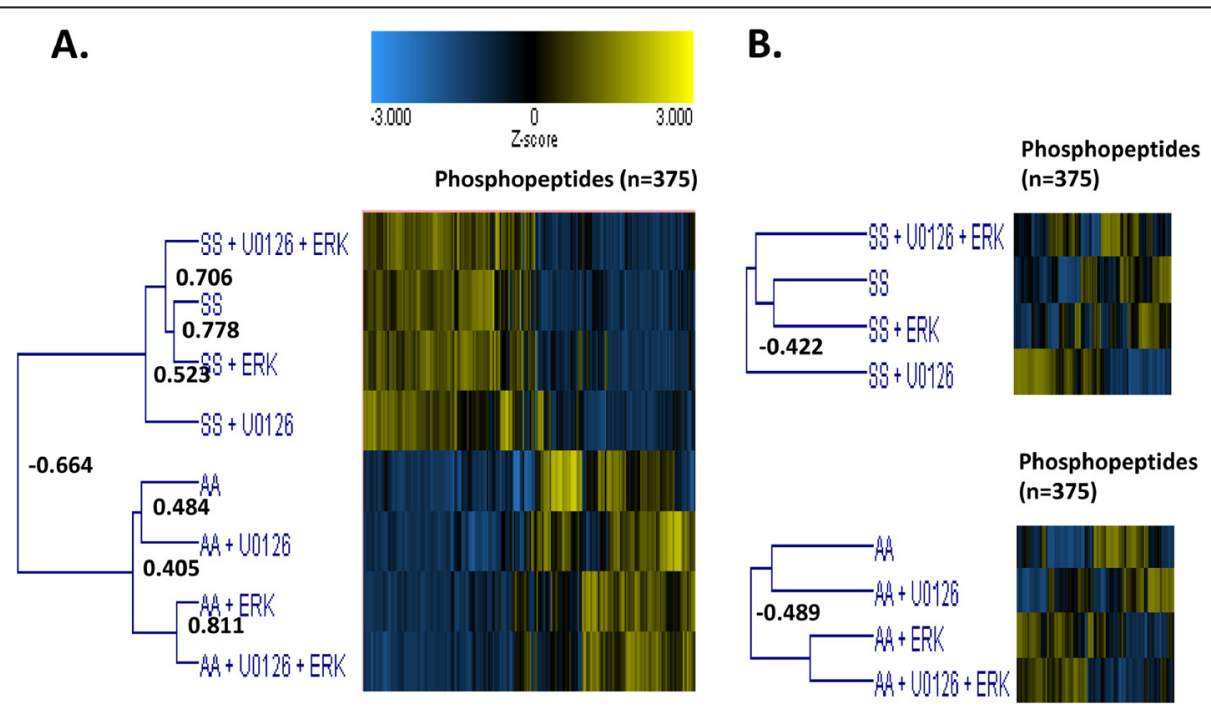

Figure 3 Two-dimensional (2D) agglomerative cluster analysis using Z-score transformed phosphopeptide intensities across eight unique RBC treatment groups. Person correlations were used as the measure of similarity $(-1$ dissimilar, +1 identical) and are shown at each branch point. (A) RBCs from healthy (AA) and sickle cell (SS) patients pre-treated with or without the MEK1/2 inhibitor, U0126, followed by preparation of membrane ghosts, and their subsequent co-incubation with or without activated recombinant ERK2. (B) Cluster analysis performed only on SS (top panel) or AA (bottom panel) RBC treatment groups. 
absence of U0126 (Pearson correlation, -0.422) (Figures 3B, top panel), which supports the previous observation that ERK $1 / 2$ is constitutively hyperactive in these sickle RBCs and that inhibiting ERK1/2's upstream activator, MEK1/2, alters a number of signaling events. Recovery from the U1026 treatment by addition of exogenous active ERK2 resulted in the phosphorylation profile becoming more similar to the non-treated SS RBCs (Figure 3B, top panel). In comparison, clustering of all phosphopeptides within only the AA RBC samples revealed the strongest differentiating factor was the addition of exogenous active ERK2 $(-0.489)$ (Figure 3B, bottom panel), which is consistent with the normal inactivity of ERK1/2 in AA RBCs, and suggests that ERK1/2 signaling is indeed mediating downstream phosphorylation of a number of targets.

Putative downstream targets specific to MEK1/2dependent activation of ERK1/2 were initially identified in SS RBCs, in which 36 unique phosphopeptides (from 21 unique phosphoproteins) decreased in abundance upon treatment with U0126. Basal ERK1/2 is already active in SS RBCs and inactive in AA RBCs [18]. Therefore, in an effort to keep the focus on the pathophysiological relevant effect of the abnormal activation of MEK1/2/ERK1/2 signaling on $\mathrm{RBC}$ membrane protein phosphorylation, we have presented the most physiologically relevant treatment group comparisons: AA vs SS RBCs, SS vs SS $\mathrm{RBCs}+\mathrm{U} 0126, \mathrm{SS}$ vs SS RBCs+ERK2, SS+U0126 vs SS $\mathrm{RBCs}+\mathrm{U} 0126+\mathrm{ERK} 2$, and AA vs AA RBCs+ERK2 in Table 2. Because label-free proteomics analysis revealed that MEK1/2/ERK1/2 signal to down-regulate 36 phosphopeptides in SS RBCs, it was important to determine the pathophysiological relevance of the abundance of these phosphopeptides by first showing that their levels were down-regulated in AA RBCs compared to SS RBCs. Comparison of individual phosphopeptide intensities between SS and AA RBCs indicates that out of these 36 phosphorylated peptides in SS RBCs, the abundance of only 25 of these phosphopeptides were decreased in AA RBCs. A negative feedback mechanism to down-regulate phosphorylation of the 25 phosphopeptides may be inactive in SS RBCs. For instance, SS RBCs have significantly higher levels of cAMP than AA RBCs [18], and PKA has been shown to exert a negative feedback loop through activation of phosphodiesterases, resulting in CAMP hydrolysis switching off downstream signaling [37]. While the MEK1/2 inhibitor U0126 was able to down-regulate these 36 unique phosphopeptides in SS RBCs, incubation of SS RBC membrane ghosts with recombinant active ERK2 in contrast, failed to increase abundance of these 36 phosphopeptides in SS RBCs (Table 2). This suggests that these peptides are already affected in SS RBCs by MEK/1/2/ERK1/2 signaling cascade, and do not necessitate further modification by exogenous ERK2. Furthermore, recombinant ERK2 was not able to fully (100\%) bring up to baseline the abundance of all phosphopeptides down-regulated by U0126. As a result, 28 of these phosphopeptides did not reach the significant fold-increase of $>1.75$ (Table 2).

We analyzed a number of these phosphoproteins referring first to the model of red blood cell membrane functional organization proposed by Anong WA et al. who identified two major protein complexes bridging the RBC membrane to cytoskeleton network: the junctional complex formed by band 3, glycophorin C, Rh group, glucose transporter, dematin, p55, adducin, band 4.1 and 4.2 with associated glycolytic enzymes and the ankyrin complex formed by band 3, glycophorin A, Rh group, ankyrin, and protein 4.2. Both complexes participate in anchoring the membrane to the actins, and $\alpha$ - and $\beta$-spectrins network, involving also other peripheral proteins as tropomyosin and tropomodulin [38]. Here, we found that MEK1/2-dependent ERK1/2 activation in SS RBCs affected membrane-bound proteomes of both the junctional and ankyrin complexes, including dematin, $\alpha-$ and $\beta$-adducins, and glycophorin $\mathrm{A}$.

Glycophorin A was the most affected protein in SS RBCs as a result of ERK1/2 activation, with 12 unique phosphorylated peptides (8 unique phosphorylated residues) being decreased in response to U0126 treatment (Table 2). The abundance of 7 of the phosphorylated residues, which were down-regulated with U0126 treatment of SS RBCs, were up-regulated in AA RBCs when exogenous active ERK2 was added to RBC membrane ghosts, suggesting that increased phosphorylation of glycophorin A by MEK1/2/ERK1/2 signaling could potentially affect SS RBC membrane properties (Table 2). To assess the changes of these phosphopeptides across the most relevant treatment groups, Z-score transformed trend plot analysis were performed and glycophorin A phosphopeptides were grouped by those which decreased in SS RBCs, and correspondingly did (top panel, 5 unique peptides) or did not (bottom panel, 7 unique peptides) increased in AA RBCs with addition of active ERK2 to the membrane ghosts (Figure 4A). For those phosphopeptides which resulted in a corresponding increase in AA RBCs with addition of recombinant ERK2, trend plot analysis were performed across all eight treatment groups (Figure 4B).

Glycophorin A, is the major sialoglycoprotein and increased SS RBC adhesion to vascular endothelial cells has been postulated to result from clustering of negatively charged glycophorin-linked sialic acid moieties at the RBC surface [6,39]. Enhanced SS RBC adhesion may also result from increased phosphorylation of glycophorin $A$ by $M E K / 1 / 2 / E R K 1 / 2$ signaling. In addition, modulation in glycophorin A phosphorylation may also affect glycophorin A interactions with band 3, which could result in decreased in both anion transport by band 3 and band 3 trafficking. 
Table 2 Differentially regulated phosphopeptides in SS RBCs in response to MEK1/2 inhibitor U0126

\begin{tabular}{|c|c|c|c|c|c|c|}
\hline Protein description & Modified peptide sequence & $\begin{array}{l}\text { AA vs SS: } \\
\text { Fold Change } \\
\text { (p-value) }\end{array}$ & $\begin{array}{l}\text { SS vs SS+U0126: } \\
\text { Fold change } \\
\text { (p-value) }\end{array}$ & $\begin{array}{l}\text { SS vs SS+ERK2: } \\
\text { Fold change } \\
\text { (p-value) }\end{array}$ & $\begin{array}{c}\text { SS+U0126 vs } \\
\text { SS+U0126+ERK2: } \\
\text { Fold change } \\
\text { (p-value) }\end{array}$ & $\begin{array}{l}\text { AA vs } A A+E R K 2: \\
\text { fold change } \\
\text { (p-value) }\end{array}$ \\
\hline $\begin{array}{l}605 \text { acidic ribosomal } \\
\text { protein } \mathrm{P} 2\end{array}$ & KEES*EES*DDDMGFGLFD & $4.8(7.24 \mathrm{E}-20)$ & $-2.1(3.61 \mathrm{E}-08)$ & NS & NS & NS \\
\hline $\begin{array}{l}\text { Adenylyl cyclase- } \\
\text { associated protein } 1\end{array}$ & SGPKPFSAPKPQTS*PSPK & NS & $-4.8(2.00 \mathrm{E}-03)$ & NS & $5.3(2.00 \mathrm{E}-04)$ & NS \\
\hline Alpha-adducin & QKGS*EENLDEAR & $2.5(2.43 \mathrm{E}-33)$ & $-4.1(2.80 \mathrm{E}-45)$ & NS & $2.4(1.25 \mathrm{E}-11)$ & NS \\
\hline Beta-adducin & ETAPEEPGS*PAKS*APAS*PVQSPAK & $5.6(3.72 \mathrm{E}-28)$ & $-1.9(3.87 \mathrm{E}-09)^{*}$ & NS & NS & $2.4(4.21 \mathrm{E}-06)^{*}$ \\
\hline Beta-adducin & ETAPEEPGSPAKS*APAS*PVQSPAK & NS & $-1.8(1.80 \mathrm{E}-02)^{*}$ & NS & $1.8(3.00 \mathrm{E}-02)$ & $1.8(2.00 \mathrm{E}-02)^{*}$ \\
\hline Beta-adducin & TESVTSGPMSPEGSPSKS*PSK & NS & $-1.9(3.00 \mathrm{E}-02)$ & NS & 1.9 (3.00E-03) & NS \\
\hline Dematin & QPLTSPGSVS*PSR & $7.9(8.63 \mathrm{E}-05)$ & $-4.4(1.00 \mathrm{E}-03)$ & NS & NS & NS \\
\hline $\begin{array}{l}\text { E3 ubiquitin-protein } \\
\text { ligase UBR4 }\end{array}$ & T*SPADHGGSVGSESGGSAVDSVAGEHSVSGR & $3.6(1.55 \mathrm{E}-18)$ & $-1.8(1.02 \mathrm{E}-07)$ & NS & NS & NS \\
\hline $\begin{array}{l}\text { Eukaryotic translation } \\
\text { initiation factor } 4 \mathrm{~B}\end{array}$ & SQS*SDTEQQSPTSGGGK & $5.6(9.74 \mathrm{E}-06)$ & $-2.5(4.00 \mathrm{E}-03)$ & NS & $2.0(2.00 \mathrm{E}-02)$ & NS \\
\hline $\begin{array}{l}\text { facilitated glucose } \\
\text { transporter member } 1\end{array}$ & QGGAS*QSDKTPEELFHPLGADSQV & $5.0(7.45 \mathrm{E}-10)$ & $-3.4(7.99 \mathrm{E}-08)$ & NS & NS & NS \\
\hline Glycophorin-A & KS*PSDVKPLPSPDTDVPLSSVEIENPETS*DQ & $7.7(9.74 \mathrm{E}-07)$ & $-1.9(2.10 \mathrm{E}-02)$ & NS & NS & $2.0(5.00 \mathrm{E}-03)$ \\
\hline Glycophorin-A & KSPSDVKPLPS*PDT*DVPLS*SVEIENPETSDQ & $10.2(1.05 \mathrm{E}-06)$ & $-2.3(5.00 \mathrm{E}-03)$ & NS & NS & $2.1(8.04 \mathrm{E}-04)$ \\
\hline Glycophorin-A & S*PS*DVKPLPSPDTDVPLSSVEIENPETS*DQ & $6.3(9.08 \mathrm{E}-07)$ & $-2.0(1.60 \mathrm{E}-02)$ & NS & NS & $1.9(3.10 \mathrm{E}-02)$ \\
\hline Glycophorin-A & S*PS*DVKPLPSPDTDVPLSSVEIENPETSDQ & $6.3(9.08 \mathrm{E}-07)$ & $-2.0(8.00 \mathrm{E}-03)$ & NS & NS & NS \\
\hline Glycophorin-A & SPSDVKPLPS*PDT*DVPLS*SVEIENPETSDQ & $7.4(8.28 \mathrm{E}-06)$ & $-1.9(2.90 \mathrm{E}-02)$ & NS & NS & $1.9(6.00 \mathrm{E}-03)$ \\
\hline Glycophorin-A & SPSDVKPLPS*PDT*DVPLSSVEIENPETSDQ & $5.0(0.00 \mathrm{E}+00)$ & $-2.0(2.13 \mathrm{E}-07)$ & NS & NS & NS \\
\hline Glycophorin-A & SPSDVKPLPSPDT*DVPLS*SVEIENPETSDQ & $5.0(0.00 \mathrm{E}+00)$ & $-1.8(4.80 \mathrm{E}-02)$ & NS & NS & NS \\
\hline Glycophorin-A & SPSDVKPLPSPDT*DVPLSSVEIENPETSDQ & $5.0(0.00 \mathrm{E}+00)$ & $-2.0(2.59 \mathrm{E}-21)$ & NS & NS & NS \\
\hline Glycophorin-A & SPSDVKPLPSPDTDVPLS*S*VEIENPETSDQ & $5.1(3.49 \mathrm{E}-06)$ & $-2.2(3.00 \mathrm{E}-03)$ & NS & NS & 2.7 (7.97E-05) \\
\hline Glycophorin-A & SPSDVKPLPSPDTDVPLSS*VEIENPETSDQ & NS & $-1.9(3.30 \mathrm{E}-07)$ & NS & NS & NS \\
\hline Glycophorin-A & SPSDVKPLPSPDTDVPLSSVEIENPET*SDQ & NS & $-1.9(1.82 \mathrm{E}-13)$ & NS & NS & NS \\
\hline Glycophorin-A & SPSDVKPLPSPDTDVPLSSVEIENPETS*DQ & NS & $-1.8(4.00 \mathrm{E}-03)$ & NS & NS & NS \\
\hline $\begin{array}{l}\text { Leucine-rich repeats and } \\
\text { immunoglobulin-like } \\
\text { domains protein } 2\end{array}$ & T*HPETIILRGMNVTLTCTAVSSSDSPMST*VWR & NS & $-2.9(1.27 \mathrm{E}-23)$ & NS & $1.8(2.65 \mathrm{E}-05)$ & NS \\
\hline $\begin{array}{l}\text { Leucine-zipper-like } \\
\text { transcriptional regulator } \\
1\end{array}$ & MAGPGST*GGQIGAAALAGGAR & $88.6(1.70 \mathrm{E}-02)$ & $-6.5(4.50 \mathrm{E}-02)$ & NS & $6.7(4.54 \mathrm{E}-06)$ & NS \\
\hline Lipin-2 & S*GGDETPSQSSDISHVLETETIFTPSSVK $^{*}$ & $3.0(1.56 \mathrm{E}-08)$ & $-1.9(3.37 E-04)$ & NS & NS & NS \\
\hline
\end{tabular}


Table 2 Differentially regulated phosphopeptides in SS RBCs in response to MEK1/2 inhibitor U0126 (Continued)

\begin{tabular}{lllll}
\hline Metabotropic & LSHKPSDRPNGEAKT*ELCENVDPNS*PAAK & $2.4(1.61 \mathrm{E}-15)$ & $-1.9(2.95 \mathrm{E}-09)$ & NS
\end{tabular}

glutamate receptor 7

glutamate receptor

ESLKEEDES*DDDNM

15) $-1.9(2.95 \mathrm{E}-09)$

NS

alpha type-3

Protein MICAL-2

VS*S*GIGAAAEVLVNLY*MNDHRPKAQAT*SPDLESMRK

$2.8(4.14 \mathrm{E}-11) \quad-1.8(5.42 \mathrm{E}-06)$

NS

NS

NS

Protein Wnt-16 HERWNCMITAAATTAPMGASPLFGYELS*SGTK

NS $\quad-4.1(8.44 \mathrm{E}-05)$

NS

Spectrin beta chain

LS*SS*WESLQPEPSHPY

$-2.2(5.13 \mathrm{E}-05) \quad-2.0(1.90 \mathrm{E}-02)$

NS

\section{erythrocyte}

Spectrin beta chain

3.5 (4.17E-13)

-1.8 (5.56E-05)

NS

NS

NS

NS

erythrocyte

Transmembrane protein SPPGS*AAGES*AAGGGGGGGGPGVSEELTAAAAAAAADEGPAR $\quad$ NS $\quad-2.9(3.91 \mathrm{E}-05)$

$151 \mathrm{~B}$

U3 small nucleolar VVHS*FDYAAS*ILSLALAHEDETIVVGMTNGILS*VKHR

NS

$-2.9(7.39 \mathrm{E}-11)$

NS

NS

NS

RNA-associated

protein 15

Uncharacterized

VVHS FDYAS*IISLALAHT

NS

NS

$-2.9(7.39 \mathrm{E}-11) \quad$ NS

NS

$-18(9.99 \mathrm{E}-05)$

$2.2(2.00 \mathrm{E}-02)$

$-1.8(4.90 \mathrm{E}-02)$

$5.0(6.40 \mathrm{E}-38)$

$-2.0(1.96 \mathrm{E}-14)$

NS

LOC388588

UV excision repair EDKS*PSEESAPTTSPESVSGSVPSSGSSGR

NS

NS NS NS

NS

$2.2(2.40 \mathrm{E}-09)$

homolog A

36 unique phosphorylated peptides were statistically down-regulated in SS RBCs upon treatment with the MEK1/2 inhibitor U0126 (SS vs SS+U0126). Of these 36, 8 phosphopeptides had their levels increased back to near basal levels upon exogenous addition of active ERK2 (SS+U0126 vs SS+U0126+ERK2). Thirteen of these phosphorylated peptides were also observed to be increased in AA RBCs upon exogenous addition of active ERK2 (AA vs AA+ERK2), suggesting specificity of downstream ERK activity. p-values $<0.05$ indicate the statistically significant variances associated with differences within triplicates for that particular comparison. Biological variances associated with differences within groups are not included in these p-values. $\left(^{*}\right)$ indicates previously reported values [18]. NS, which refers to non-significant, indicates that a statistically significant change (based on 1.75 fold-changes and $p$-value $<0.05$ ) was not measured. 


\section{A}

Glycophorin-A phosphopeptides down-regulated in SS in response to U0126 and concurrently up-regulated in AA in response to ERK

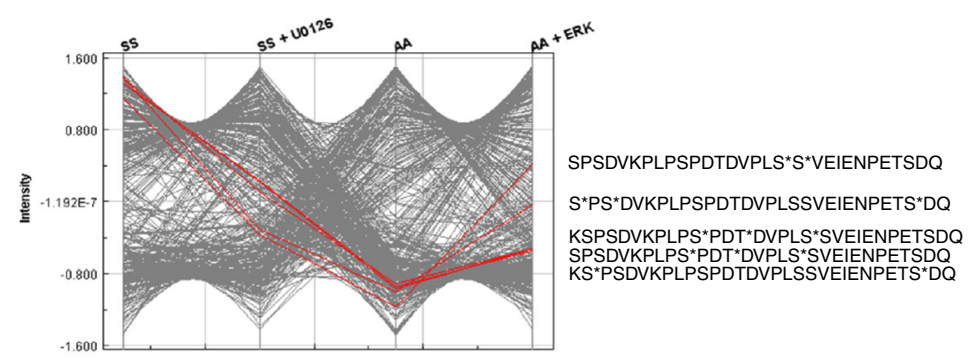

Glycophorin-A phosphopeptides down-regulated in SS in response to U0126 and not up-regulated in AA in response to ERK

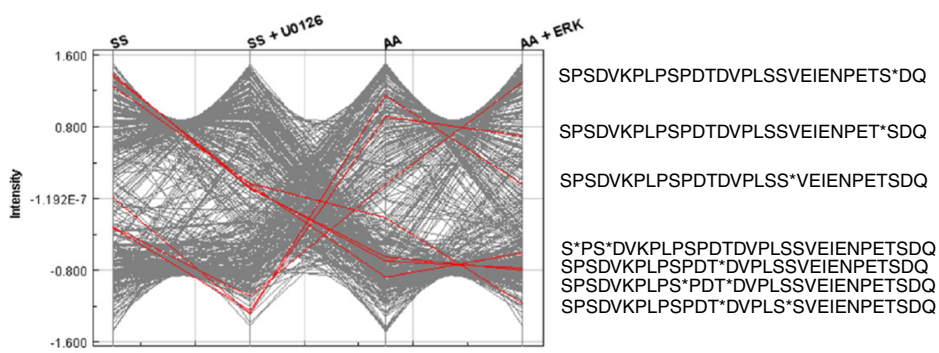

B

\begin{tabular}{|c|c|c|}
\hline $\begin{array}{l}\text { S*PS*DVKPLPSPDTDVPLS }^{*} \\
\text { SVEIENPETS*DQ }\end{array}$ & $\begin{array}{l}\text { SPSDVKPLPS*PDT*DVPLS } \\
\text { SVEIENPETSDQ }\end{array}$ & $\begin{array}{l}\text { SPSDVKPLPSPDTDVPLS } \\
\text { S VEIENPETSDQ }^{*}\end{array}$ \\
\hline
\end{tabular}
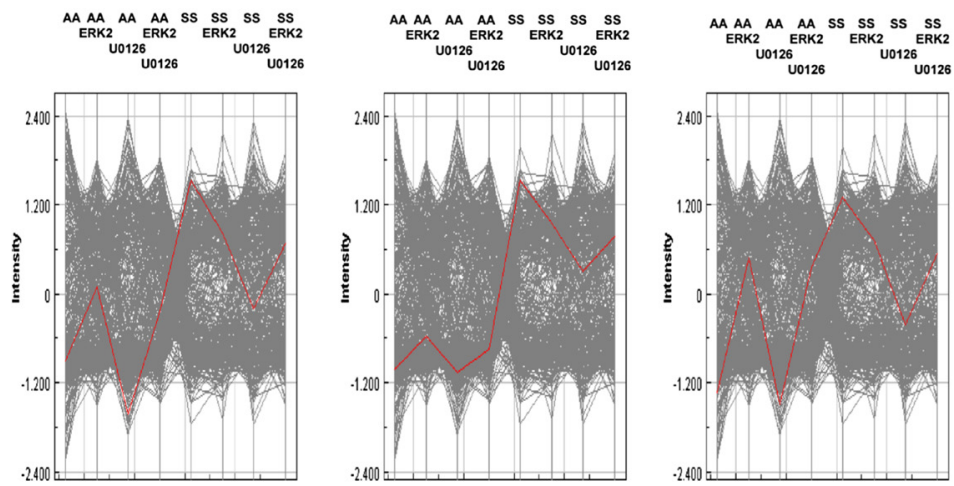

KS*PSDVKPLPSPDTD VPLSSVEIENPETS*DQ

KSPSDVKPLPS^PDT^D VPLS*SVEIENPETSDQ
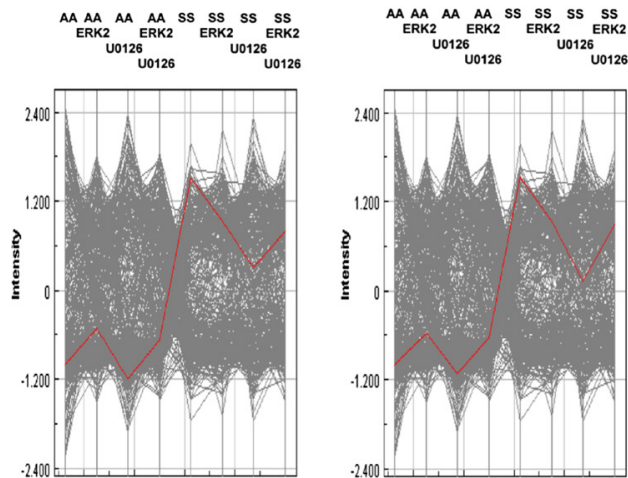

Figure 4 (See legend on next page.) 
Figure 4 Trend plot analysis of differentially expressed glycophorin-A phosphopeptides. (A) Z-Score transformed phosphopeptide intensities of glycophorin-A peptides, which decreased in abundance in SS RBCs upon treatment with U0126 (indicated in Table 2) were differentiated into groups, which either did or did not increased in AA RBCs upon addition of recombinant active ERK2 to the membrane ghosts, and plotted across four relevant treatment groups. (B) Five glycophorin-A phosphorylated peptides, which both decreased in SS RBCs upon treatment with U0126 and increased in AA RBCs upon addition of active ERK2 to the membrane ghosts plotted across all eight treatment groups. Each data-point is plotted as an average of three technical replicates. An $\left(^{*}\right)$ within the peptide sequence indicates the preceding residue is phosphorylated.

Our data also indicated that adducin- $\beta$ contained three unique phosphorylated peptides, with phosphorylation of residues within the ERK1/2 consensus motif [18], suggesting that the cytoskeletal protein adducin- $\beta$ is a substrate for ERK1/2 in RBCs (Table 2). A decrease in phosphorylation of these peptides was observed in U0126-treated SS RBCs, while an increase in phosphorylation was observed in both U0126-treated SS RBCs and in AA RBCs when recombinant active ERK2 was added to the membrane ghosts. However, the phosphorylated serine on either adducin- $\alpha$ or dematin, was not within the ERK1/2 consensus motif [18]. Phosphorylation of cytoskeletal proteins by ERK1/2 in SS RBCs may lead to cytoskeletal disorganization [14,40-43], which in turn, could potentially affect RBC adhesiveness. Our previous study has indeed shown that ERK1/2 regulates SS $\mathrm{RBC}$ adhesion to the endothelium [18]. Furthermore, while protein 4.1 in SS RBCs is extensively phosphorylated [14] with 17 uniquely phosphorylated peptides and 13 unique phosphorylated residues (Table 1), based on the chosen threshold fold-increase of $>1.75$ for this study, increased phosphorylation of protein 4.1 seems to not involve ERK1/2 signaling.

MEK1/2/ERK1/2 signaling in SS RBCs induced changes within the actins/spectrins network as well by affecting phosphorylation of $\beta$-spectrins (Table 2). Erythrocyte spectrin, the major component of the membrane skeleton, undergoes a number of naturally occurring or pathologically induced posttranslational phosphorylation via a cAMPdependent protein kinase $[44,45]$, which has been shown to act upstream of ERK1/2 in SS RBCs [18]. ${ }^{32}$ P-labeling studies indicate that only the $\beta$-subunit of spectrin is phosphorylated in intact erythrocyte $[44,46-48]$, and an increase in $\beta$-spectrin phosphorylation by casein kinase I causes a decrease in erythrocyte membrane mechanical stability [49].

Furthermore, this analysis revealed that the peptide metabotropic glutamate receptor 7 (mGlu7) underwent serine phosphorylation at the ERK consensus motif (Table 2). In addition, a phosphopeptide detected within mGlu7 in our dataset was increased in SS RBCs by 2.4fold compared to healthy AA RBCs. Gu et al. have also shown that mGluR7 activation occurs via an ERKdependent mechanism, which increased cofilin activity and F-actin depolymerization [50]. mGLu7 acts as an autoreceptor mediating the feedback inhibition of glutamate release [51-53], and prolonged activation of this receptor potentiates glutamate release [54]. Changes were also observed in the status of leucine-rich repeats and immunoglobulin-like domains protein 2, leucinezipper-like transcriptional regulator 1 , and glucose transporter 1, but only in membrane ghosts prepared from SS RBCs treated with U0126 or after addition of exogenous active ERK2 to these membrane ghosts (Table 2). Changes in the status of these proteins by MEK $1 / 2$ / ERK1/2 signaling may potentially disturb degradation of misfolded glycoproteins and receptor ubiquitination, and affect protein transcription. Similarly, phosphorylation of adenylyl cyclase-associated protein 1 (CAP1), which was more abundant in SS vs AA RBCs, increased via the ERK1/2 signaling only in SS RBCs [18]. CAP1 is known to regulate adenylate cyclase activation to increase cAMP levels under specific environmental conditions. Indeed, basal cAMP levels are much higher in sickle than in healthy $\mathrm{RBCs}$, and CAMP/PKA can regulate ERK1/2 activation in SS RBCs [18]. CAPs are also involved in actin binding, SH3 binding, and cell morphology maintenance as well $[55,56]$. The failure of recombinant active ERK2 to significantly up-regulate the abundance of the phosphorylated peptides, leucine-rich repeats and immunoglobulin-like domains protein 2, leucine-zipper-like transcriptional regulator 1 and CAP1 in healthy RBCs suggests a negative regulatory mechanism might exist in these cells to prevent activation of ERK1/2dependent phosphorylation of these membrane proteins, such as the ability of PKA to negatively affect phosphodiesterases to switch off downstream signaling [37].

\section{ERK1/2 Signaling highly affects phosphorylation of glycophorin A}

The pharmacological stress hormone epinephrine can increase ERK1/2 activation in SS RBCs [18]. Because our discovery proteomics data indicated that the MEK1/2 inhibitor U0126 down-regulated the phosphorylation state of glycophorin $\mathrm{A}$ in a number of unique residues, we determined the contribution of activation of MEK1/2dependent ERK1/2 signaling in glycophorin A phosphorylation in intact SS RBCs. SS RBCs were therefore treated with epinephrine to increase activation of ERK1/2 in the presence or absence of the MEK inhibitor U0126 prior to 
immunoprecipitation of glycophorin A. PhosphorImager analysis of immunoprecipitated ${ }^{32} \mathrm{P}$-radiolabeled glycophorin A and negative control immune complexes showed that glycophorin A of non-stimulated SS RBCs (Figure 5, lane 1 , patient 1 ) is modestly phosphorylated at baseline, which confirms our phosphoproteomics data (Table 2). Treatment of SS RBCs with serine phosphatase inhibitors (SPI) (lane 2, patients 1; and lane 1, patient 2) slightly increased glycophorin A phosphorylation by $1.9 \pm 0.1$-fold $(p<0.05, n=3)$, suggesting that increased glycophorin A phosphorylation is a result of serine phosphorylation, as tyrosine phosphatase inhibitors were not present. Epinephrine in the presence of SPI had a stronger effect on glycophorin A phosphorylation (2.93 \pm 0.35 -fold increase over sham-treated SS RBCs; $p<0.001$ ) (lane 3, patient 1; and lane 2, patient 2). However, treatment of SS RBCs with the MEK/12 inhibitor U0126 significantly decreased the combined effect of epinephrine and SPI on glycophorin A phosphorylation (lane 4, patient 1; and lane 3, patient 2) compared to cells treated with epinephrine and SPI $(p<0.001)$ (lane 3 patient 1 ; and lane 2 , patient 2 ). Immunoblots of ${ }^{32} \mathrm{P}$-radiolabeled glycophorin A immunoprecipitates from stimulated and non-stimulated SS RBCs indicated that a similar amount of glycophorin A was immunoprecipitated from these cells (Figure 5). Our data strongly confirm that increased glycophorin A phosphorylation is dependent on MEK1/2-dependent ERK1/2 signaling pathway in SS RBCs. It has been suggested that glycophorin contains receptors or other surface recognition sites of the erythrocyte [57]. Although the conformation of glycophorin in the lipid bilayer is not known, it has also been suggested that the glycoproteins exist as aggregates in the membrane in order to facilitate receptor function [58]. However, we do not know whether increased phosphorylation of glycophorin A affects the state of aggregation of this glycoprotein. Recently, Shapiro and Marchesi have demonstrated that the site of phosphorylation of glycophorin is located on the C-terminal portion of the protein [59]. Indeed, localization of all identified phosphorylated resides in these data were located on the C-terminal 30 residues of the protein. It remains to be determined if phosphorylation plays a role in the formation of aggregates of the protein.

\section{Conclusion}

To date, a quantitative LC-MS based analysis of global phosphorylation events in a membrane fraction of sickle $\mathrm{RBCs}$ has not been reported in the literature. Here we applied a label-free quantitative phosphoproteomic strategy to characterize signaling pathways from healthy and sickle $\mathrm{RBC}$ membrane fractions in the presence or absence of a specific MEK1/2 inhibitor with and without subsequent ERK2 activation. The analysis resulted in the quantitation of 375 phosphopeptides from 155 unique phosphoproteins with an average technical coefficient of variation in peak intensity of $19.8 \%$. Gene ontology

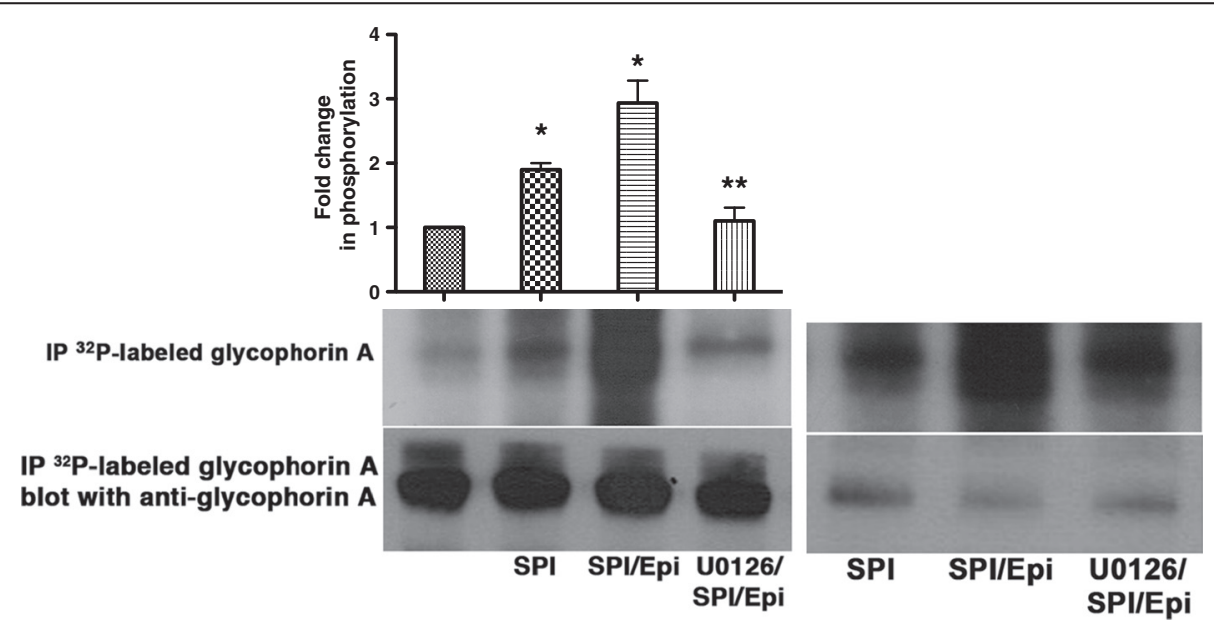

Patient 1

Patient 2

Figure 5 ERK1/2 signaling up-regulates glycophorin A serine phosphorylation. Inorganic ${ }^{32} \mathrm{P}$ radiolabeled intact SS RBCS were incubated in the absence (patient 1: lane 1) or presence (patients 1: lanes 2, 3 and 4; and patient 2: lanes 1, 2 and 3) of serine/threonine protein phosphatase inhibitors (SPI), not followed (patient 1: lanes 1 and 2; and patient 2: lane 1) or followed by treatment with epinephrine (epi) (patient 1: lanes 3 and 4; and patient 2: lanes 2 and 3). In lane 4 (patient 1) and lane 3 (patient 2), SS RBCs were preincubated with MEK1/2 inhibitor U0126 prior to treatment with SPI followed by epi treatment. The Fold change in phosphorylation is representative of three different experiments, calculated after subtraction of cpm present in a lane (not shown) containing immunoprecipitates using immunoglobulin P3 from cpm obtained using anti-glycophorin A mAb for immunoprecipitation under each set of conditions indicated. * $: p<0.05$ and $p<0.001$ for SPI-treated and SPI+epitreated vs. sham-treated, respectively; ${ }^{* *}: p<0.001$ compared to SPI+epi-treated SS RBCs. Total glycophorin A loaded in each lane was detected using nitrocellulose membranes of phosphorylated glycophorin A blotted with anti-glycophorin A mAb. 
analysis revealed that nearly a third of the identified phosphoproteins are involved in binding as their primary biological function. This is of considerable importance as the primary hallmark of sickle cell disease is the ability of RBCs to abnormally interact with endothelial cells, leukocytes and platelets, and these cell-cell interactions are mediated through activation of RBC surface adhesion receptors. It is important to note that the goal of this work was to perform a discovery experiment to identify candidate proteins differentially regulated by the ERK $1 / 2$ signaling pathway (Table 2). As we knew biological replications would not be available, we addressed the replication of the most biologically relevant and novel findings (phosphorylation of glycophorin A) through additional biochemical assays on replicate patients (Figure 5).

Phosphopeptide quantitation across all eight unique treatment groups indicate that the ERK1/2 pathway activation in SS RBCs could be responsible for alteration of multiple phenotypic and functional properties of the red cell, by affecting phosphorylation of thirty-six peptides from twenty-one phosphoproteins involved in adhesion, cAMP production, anion transport by band 3 and band 3 trafficking, RBC shape, flexibility, cell morphology maintenance, glucose and glutamate transport, degradation of misfolded proteins, and receptor ubiquitination, all of which play a significant role in the complex pathophysiology of the disease. Interestingly, these data revealed that glycophorin A phosphorylation was highly differentiated between healthy and sickle RBCs, and its levels of phosphorylation were modulated by the presence of the MEK1/2 inhibitor U0126 and the presence of exogenously spiked ERK2. Glycophorin A is the major sialoglycoprotein, and increased SS RBC adhesion to vascular endothelial cells has been postulated to result from clustering of negatively charged glycophorin-linked sialic acid moieties at the RBC surface [6,39]. In addition, alteration in glycophorin A phosphorylation could subsequently result in decreases in both anion transport by band 3 and band 3 trafficking. Thus, our studies further confirm ERK1/2 as a potential therapeutic target to ameliorate multiple functions of the sickle red cell, including adhesion [18] and vaso-occlusion [10,18], chronic hemolysis and ischemic tissue damage [7], all of which are associated with the pathophysiology of SCD. Finally, follow-up validations will be addressed on additional physiologically relevant molecules presented in Table 2, such as cytoskeletal proteins, and the effect of their phosphorylation by ERK1/2 on RBC function.

\section{Materials and methods}

\section{Collection, preparation and treatment of RBCs}

Human SCD patients homozygous for hemoglobin S were not transfused for at least three months, had not experienced vaso-occlusion for three weeks and were not on hydroxyurea. Blood samples from SCD patients and healthy donors collected into citrate tubes, were used within less than $24 \mathrm{~h}$ of collection. Packed RBCs were separated as previously described in detail [60]. Packed RBCs were analyzed for leukocyte and platelet contamination using an Automated Hematology Analyzer K-1000 (Sysmex, Japan). For proteomics studies, aliquots of packed $\mathrm{RBCs}$ were treated at $37^{\circ} \mathrm{C}$ for $1 \mathrm{~h}$ with $10 \mu \mathrm{M}$ MEK1/2 inhibitor U0126 dissolved in dimethyl sulfoxide (DMSO). Sham-treated RBCs were incubated with the same buffer and vehicle, but without the active agent. Normal RBCs were used as controls.

\section{MAP kinase activity assay}

Treated packed normal and SS RBCs were lysed at $4^{\circ} \mathrm{C}$ with lysis buffer (10 mM EDTA, $20 \mathrm{mM}$ Tris, $110 \mathrm{mM}$ $\mathrm{NaCl}$, pH 7.5) containing $2 \mathrm{mM}$ PMSF, 1\% Triton $\mathrm{X}-100$, phosphatase inhibitor cocktail (Sigma-Aldrich, St. Louis, MO) and protease inhibitor cocktail (Sigma). RBC membrane ghosts were then incubated with or without recombinant active human ERK2 (Sigma) at $8.2 \mu \mathrm{g} / \mathrm{ml}$ with a specific activity of $700 \mathrm{nmole} / \mathrm{min} / \mathrm{mg}$, in the presence of inhibitors of PKA, PKC, $\mathrm{Ca}^{2+} /$ calmodulindependent kinase and $\mathrm{p} 34^{\mathrm{cdc} 2}$ kinase to prevent nonspecific protein phosphorylation by these enzymes [61], and with ATP as a phosphate donor with equal membrane ghost protein amounts per assay condition. For the negative control, an equal volume of water was substituted for ATP. The reaction mixture was incubated for $20 \mathrm{~min}$ at $30^{\circ} \mathrm{C}$. To stop the enzymatic reaction samples were placed on ice.

\section{RBC membrane ghost preparation and phosphopeptide enrichment}

Non-radiolabeled RBC membrane ghosts isolated from packed RBCs sham-treated or treated with U0126 and incubated with or without recombinant ERK2, were spun at $14,000 \mathrm{rpm}$ for $15 \mathrm{~min}$ at $4^{\circ} \mathrm{C}$ to pellet membranes. Membrane pellets were washed with $1 \mathrm{~mL} 50 \mathrm{mM}$ ammonium bicarbonate $(\mathrm{pH} 8.0)$ with vortexing and were then spun at $14,000 \mathrm{rpm}$ for $30 \mathrm{~min}$ at $4^{\circ} \mathrm{C}$. The supernatant was then removed and $500 \mu \mathrm{L}$ of $0.2 \%$ acid-labile surfactant ALS-1 (synthesized in house according to $\mathrm{Yu}$ et al. [62]) in $50 \mathrm{mM}$ ammonium bicarbonate $(\mathrm{pH} 8.0)$ was added. Samples were subjected to probe sonication three-times for $5 \mathrm{sec}$ with cooling on ice between and insoluble material was cleared by centrifugation at $14,000 \mathrm{rpm}$ for $30 \mathrm{~min}$ at $4^{\circ} \mathrm{C}$. Samples were normalized to approximately $2 \mu \mathrm{g} / \mu \mathrm{l}$ following a micro-Bradford assay (Pierce Biotechnology, Inc), and were reduced with a final concentration of $10 \mathrm{mM}$ dithiothreitol at $80^{\circ} \mathrm{C}$ for $20 \mathrm{~min}$. Samples were then alkylated with a final concentration of $20 \mathrm{mM}$ iodoacetamide at room temperature for $45 \mathrm{~min}$ and trypsin was added to a final ratio of 1-to-50 (w/w) enzyme-to-protein 
and allowed to digest at $37^{\circ} \mathrm{C}$ for $18 \mathrm{hr}$. To remove ALS-1, samples were acidified to $\mathrm{pH} 2.0$ with neat TFA, incubated at $60^{\circ} \mathrm{C}$ for $2 \mathrm{hrs}$ and spun at $14,000 \mathrm{rpm}$ for $5 \mathrm{~min}$ to remove hydrolyzed ALS-1. Samples were either subjected to LC-MS analysis following a 10X dilution into mobile phase $\mathrm{A}$ or subjected to a $\mathrm{TiO}_{2}$ based phosphopeptide enriched protocol [34].

To enrich for phosphorylated peptides prior to LC-MS analysis, 1,125 $\mu \mathrm{g}$ of total digested protein from RBC ghosts were brought to near dryness using vacuum centrifugation and then resuspended in $200 \mu \mathrm{L}$ of $80 \%$ acetonitrile, 1\% TFA, $50 \mathrm{mg} / \mathrm{ml}$ MassPrep Enhancer (pH 2.5) (Waters Corp., Milford, MA). Samples were loaded onto an in-house packed $\mathrm{TiO}_{2}$ spin column (Protea Biosciences) with a $562 \mu \mathrm{g}$ binding capacity preequilibrated with $80 \%$ acetonitrile, $1 \%$ TFA (pH 2.5). For all loading, washing, and elution steps, the centrifuge was set to achieve a flow rate of no faster than $100 \mu \mathrm{L} / \mathrm{min}$. Samples were washed twice with $200 \mu \mathrm{L} 80 \%$ acetonitrile, 1\% TFA, $50 \mathrm{mg} / \mathrm{ml}$ MassPrep Enhancer (pH 2.5) followed by two washes with $200 \mu \mathrm{L} 80 \%$ acetonitrile, 1\% TFA ( $\mathrm{pH} 2.5$ ). Retained peptides were eluted twice with $100 \mu \mathrm{L} \mathrm{20 \%}$ acetonitrile, 5\% aqueous ammonia ( $\mathrm{pH} 10.0)$, acidified to $\mathrm{pH} 3$ with neat formic acid and then brought to dryness using vacuum centrifugation. Prior to LC-MS analysis, each sample was resuspended in $20 \mu \mathrm{L} 2 \%$ acetonitrile, $0.1 \%$ TFA, $25 \mathrm{mM}$ citric acid (pH 2.5).

\section{LC-MS/MS analysis of RBC membrane ghosts}

Chromatographic separation of phosphopeptide enriched or non-enriched samples was performed on a Waters NanoAquity UPLC equipped with a $1.7 \mu \mathrm{m}$ BEH130 $\mathrm{C}_{18}$ $75 \mu \mathrm{m}$ I.D. X $250 \mathrm{~mm}$ reversed-phase column. The mobile phase consisted of (A) $0.1 \%$ formic acid in water and (B) $0.1 \%$ formic acid in acetonitrile. Five $\mu \mathrm{L}$ injections of each sample were trapped for $5 \mathrm{~min}$ on a $5 \mu \mathrm{m}$ Symmetry $\mathrm{C}_{18} 180 \mu \mathrm{m}$ I.D. X $20 \mathrm{~mm}$ column at $20 \mu \mathrm{l} /$ min in $99.9 \%$ A. The analytical column was then switched in-line and the mobile phase was held for 5 min at $5 \% \mathrm{~B}$ before applying a linear elution gradient of $5 \%$ B to $40 \%$ B over $90 \mathrm{~min}$ at $300 \mathrm{~nL} / \mathrm{min}$. The analytical column was connected to fused silica PicoTip emitter (New Objective, Cambridge, MA) with a $10 \mu \mathrm{m}$ tip orifice and coupled to the mass spectrometer through an electrospray interface.

MS was acquired on a Thermo LTQ-Orbitrap XL mass spectrometer operating in positive-ion mode with an electrospray voltage of $2.0 \mathrm{kV}$ with real-time lockmass correction on ambient polycyclodimethylsiloxane (m/z 445.120025) enabled. The instrument was set to acquire a precursor MS scan from $\mathrm{m} / z$ 400-2000 with $\mathrm{r}=60,000$ at $\mathrm{m} / z 400$ and a target AGC setting of $1 \mathrm{e} 6$ ions. MS/MS spectra were acquired in the linear ion-trap for the top 5 most abundant precursor ions above a threshold of 500 counts. Maximum fill times were set to $1000 \mathrm{~ms}$ for full MS scans acquired in the OT and $250 \mathrm{~ms}$ for MS/MS acquired in the linear ion trap, with a CID energy setting of $35 \%$ and a dynamic exclusion of $60 \mathrm{~s}$ for previously fragmented precursor ions. Multistage activation (MSA) for neutral losses of 98.0, 49.0, and 32.33 Da was enabled to enhance fragmentation of phosphorylated peptides.

\section{Label-free quantitation and database searching}

Label-free quantitation and integration of qualitative peptide identifications was performed using Rosetta Elucidator (v 3.3, Rosetta Inpharmatics, Seattle, WA). All raw LC-MS/MS data were imported and subjected to chromatographic retention time alignment using the PeakTeller ${ }^{\circledR}$ algorithm with a minimum peak time width set to $6 \mathrm{~s}$, alignment search distance set to $4 \mathrm{~min}$ and the refine alignment option enabled. Quantitation of all detected signals in the precursor MS spectra was performed within Elucidator following the generation of extracted ion chromatograms for each detected precursor ion. Fold-change values between treatment groups were calculated on the phosphopeptide level from the averages of the sum of all features associated with the precursor ion within a technical replicate. To account for slight differences in total peptide loading between injections, all of the features within an LC-MS analysis were subjected to a robust mean normalization of all of the feature intensities, which excluded the highest and lowest $10 \%$ of the signals.

Qualitative peptide identifications were made by generating DTA files for all precursor ions, which had associated MS/MS spectra. DTA files were submitted to Mascot (version 2.2.04, Matrix Science, Boston, MA) and searched against a Homo sapiens protein database downloaded from SwissProt concatenated with the sequence-reversed version of each entry (download March 2009, 20336 forward entries). Search tolerances of $10 \mathrm{ppm}$ precursor and $0.8 \mathrm{Da}$ product ions were applied and all data were searched using trypsin specificity with up to two missed cleavages. Static modification of Carbamidomethylation (+57.0214 Da on C) and dynamic modifications of oxidation $(+15.9949 \mathrm{Da}$ on $\mathrm{M})$ and phosphorylation (+79.9663 Da on STY) were employed. False-discovery rate were determined by adjusting the Mascot peptide ion score threshold to allow a $1 \%$ occurrence of peptide spectral matches from reverse protein entries for phosphopeptide enriched experiments.

A tabular form of the raw data, including Protein Accession number, Protein Description, Modified Peptide Sequence, ModLoc Max Score, Mascot Ion Score, and Intensities/Standard Deviation for each phosphorylated peptide within each treatment group has been uploaded as an Additional file 2. 
Glycophorin A phosphorylation and immunoprecipitation Packed RBCs ${ }^{32}$ P-labeled as previously described [63], were sham-treated, or incubated with serine/threonine phosphatase inhibitor (SPI) cocktail (Sigma) for $30 \mathrm{~min}$, SPI cocktail followed by $1 \mathrm{~min}$ treatment with $20 \mathrm{nM}$ epinephrine, or pre-incubated with $10 \mu \mathrm{M}$ U0126 for $1 \mathrm{~h}$ followed by SPI cocktail, then treated with $20 \mathrm{nM}$ epinephrine for 1 min. Cells were then washed 4 times. Glycophorin A immunoprecipitation using anti-glycophorin A monoclonal antibody (mAb) (Abcam, Cambridge, MA) and the negative control immunoglobulin P3, and total and phosphoglycophorin A detection were performed as previously described in detail [60]. To confirm that the immunoprecipitates were specific for glycophorin A, anti-glycophorin A $\mathrm{mAb}$ and the negative control P3 were used to immunoprecipitate glycophorin A from non-radiolabeled treated SS RBCs. Blots were immunostained with anti-glycophorin A mAb.

\section{Data clustering and statistical analysis}

Global characterization of phosphoproteomic profiles across all treatment groups was accomplished using twodimensional clustering within Rosetta Elucidator. Individual phosphopeptide intensities within a treatment group were averaged and then converted to a Z-score to measure significance of change rather than absolute change. Z-score corrected phosphopeptide intensities were then subjected to an agglomerative clustering algorithm, using an average link heuristic criteria. Pearson correlation metrics were used to define similarity, with a score of 1 being identical and -1 being completely dissimilar. $P$-values for phosphoproteomic data was calculated using a ratio error model [64]. $\mathrm{P}^{32}$ glycophorin-A data were compared using parametric analyses (GraphPad Prism 5 Software, San Diego, $\mathrm{CA})$, including repeated and non-repeated measures of analysis of variance (ANOVA). One-way and two-way ANOVA analyses were followed by Bonferroni corrections for multiple comparisons (multiplying the $p$ value by the number of comparisons). A $p$-value $<0.05$ was considered significant.

\section{Additional files}

Additional file 1: Figure S1. Phosphorylated residue localization and technical variation of phosphorylated peak intensity. (A) ModLoc site localization scoring distributions across all 375 unique phosphoryalted peptides from RBC ghost preparations. (B) Coefficient of variation (\%CV) distribution of measured phosphopeptide peak intensities from triplicate LC-MS analysis of a treatment group following accurate-mass and retention time alignment. Error bars indicate standard deviation within each \%CV bin across all eight treatment groups.

Additional file 2: Phosphopeptides identified in TiO2-enriched RBC membrane fractions. From left to right; protein accession number, protein description, modified peptide sequence, ModLoc Max Score, Mascot ion score, and Intensities/Standard Deviation for each phosphorylated peptide within each treatment group.
Additional file 3: Figure S2. Inter-treatment group variation of ERK phosphorylated peptide. Selected ion chromatogram (A) and peak quantitation (B) of 173-VADPDHDHTGFLTE[pY]VATR-191 $\left([\mathrm{M}+3 \mathrm{H}]^{3+}\right.$ $741.999 \mathrm{~m} / \mathrm{z}$ ), the active form of Mitogen-Activated Protein Kinase-1 (SwissProt_MAPK1, ERK1/2), across 24 LC-MS injections. This peptide was qualitatively identified with a maximum mascot ion score of 63.3 and a site localization ModLoc score of $41+/-12$.

\section{Competing interests}

The authors declare no competing financial interests.

\section{Authors' contributions}

E.S. performed mass spectrometry separation and label-free phosphopeptide enrichment experiments, participated in the interpretation of the corresponding data, generated the graphs for proteomic data and wrote the manuscript; W.T. helped design proteomic experiments and interpret the corresponding data, and helped edit the manuscript; E.S. helped perform some of the Western blot experiments related to glycophorin A phosphorylation; E.C. helped perform the Western blot experiments related to glycophorin A phosphorylation; L.D. helped perform mass spectrometry sample preparation A.M. helped edit the manuscript; and R.Z. conceived the hypothesis, designed and led the project, prepared the samples for mass spectrometry separation and label-free phosphopeptide enrichment experiments, performed and generated the data for immunoprecipitation experiments, analyzed and interpreted the data and wrote the manuscript. All authors read and approved the final manuscript.

\section{Acknowledgements}

This work was supported by grants DK065040 to RZ from NIDDK, NIH, a National Blood Foundation award to RZ.

\section{Author details}

'Proteomics Core Facility, Duke University Medical Center, Durham, NC, USA. ${ }^{2}$ Division of Hematology and Duke Comprehensive Sickle Cell Center, Department of Medicine, Duke University Medical Center, Durham, NC, USA.

${ }^{3}$ Duke University Medical Center, Box 2615, Durham, NC 27710, USA.

Received: 26 June 2012 Accepted: 19 December 2012

Published: 3 January 2013

\section{References}

1. Nagel RL PO: In Disorders of haemoglobin: genetics, pathophysiology, clinical management. Edited by Steinberg MH, Forget BG, Higgs DR. Cambridge UK: Cambridge University Press; 2001:494-526.

2. Eaton $W A$, Hofrichter J: Sickle cell hemoglobin polymerization. Adv protein Chem 1990, 40:63-279.

3. Hebbel RP, Eaton JW, Balasingam M, Steinberg MH: Spontaneous oxygen radical generation by sickle erythrocytes. J Clin Invest 1982, 70(6):1253-1259.

4. Brugnara C, De Franceschi L, Bennekou P, Alper SL, Christophersen P: Novel therapies for prevention of erythrocyte dehydration in sickle cell anemia. Drug news \& perspectives 2001, 14(4):208-220.

5. Steinberg MH: Management of sickle cell disease. N Engl J Med 1999, 340(13):1021-1030.

6. Hebbel RP, Boogaerts MA, Eaton JW, Steinberg MH: Erythrocyte adherence to endothelium in sickle-cell anemia. A possible determinant of disease severity. N Engl I Med 1980, 302(18):992-995.

7. Rodgers GP: Overview of pathophysiology and rationale for treatment of sickle cell anemia. Semin Hematol 1997, 34(3 Suppl 3):2-7.

8. Browne PV, Shalev O, Kuypers FA, Brugnara C, Solovey A, Mohandas N, Schrier SL, Hebbel RP: Removal of erythrocyte membrane iron in vivo ameliorates the pathobiology of murine thalassemia. J Clin Invest 1997, 100(6):1459-1464.

9. de Franceschi L, Shalev O, Piga A, Collell M, Olivieri O, Corrocher R, Hebbel RP, Brugnara C: Deferiprone therapy in homozygous human betathalassemia removes erythrocyte membrane free iron and reduces $\mathrm{KCl}$ cotransport activity. J Lab Clin Med 1999, 133(1):64-69.

10. Zennadi R, Moeller BJ, Whalen EJ, Batchvarova M, Xu K, Shan S, Delahunty M, Dewhirst MW, Telen MJ: Epinephrine-induced activation of LWmediated sickle cell adhesion and vaso-occlusion in vivo. Blood 2007, 110(7):2708-2717. 
11. Terra HT, Saad MJ, Carvalho CR, Vicentin DL, Costa FF, Saad ST: Increased tyrosine phosphorylation of band 3 in hemoglobinopathies. Am J Hematol 1998, 58(3):224-230.

12. Siciliano A, Turrini F, Bertoldi M, Matte A, Pantaleo A, Olivieri O, De Franceschi L: Deoxygenation affects tyrosine phosphoproteome of red cell membrane from patients with sickle cell disease. Blood Cells Mol Dis 2010, 44(4):233-242.

13. Gauthier E, Guo X, Mohandas N, An X: Phosphorylation-dependent perturbations of the 4.1R-Associated multiprotein complex of the erythrocyte membrane. Biochem 2011, 50(21):4561-4567.

14. George A, Pushkaran S, Li L, An X, Zheng Y, Mohandas N, Joiner CH, Kalfa TA: Altered phosphorylation of cytoskeleton proteins in sickle red blood cells: the role of protein kinase C, Rac GTPases, and reactive oxygen species. Blood Cells Mol Dis 2010, 45(1):41-45.

15. Culliford SJ, Ellory JC, Gibson JS, Speake PF: Effects of urea and oxygen tension on K flux in sickle cells. Pflugers Archiv: Eur J Physiol 1998, 435(5):740-742.

16. Kahle KT, Rinehart J, Lifton RP: Phosphoregulation of the Na-K-2Cl and $\mathrm{K}-\mathrm{Cl}$ cotransporters by the WNK kinases. Biochim Biophys Acta 2010, 1802(12):1150-1158.

17. Fathallah $\mathrm{H}$, Sauvage $M$, Romero JR, Canessa M, Giraud F: Effects of PKC alpha activation on $\mathrm{Ca} 2+$ pump and $\mathrm{K}(\mathrm{Ca})$ channel in deoxygenated sickle cells. Am J Physiol 1997, 273(4 Pt 1):C1206-C1214.

18. Zennadi R, Whalen EJ, Soderblom EJ, Alexander SC, Thompson JW, Dubois LG, Moseley MA, Telen MJ: Erythrocyte plasma membrane-bound ERK1/2 activation promotes ICAM-4-mediated sickle red cell adhesion to endothelium. Blood 2012, 119:1217-1227.

19. Gauthier E, Rahuel C, Wautier MP, El Nemer W, Gane P, Wautier JL, Cartron JP, Colin Y, Le Van Kim C: Protein kinase a-dependent phosphorylation of lutheran/basal cell adhesion molecule glycoprotein regulates cell adhesion to laminin alpha5. J Biol Chem 2005, 280(34):30055-30062.

20. Kakhniashvili DG, Griko NB, Bulla LA Jr, Goodman SR: The proteomics of sickle cell disease: profiling of erythrocyte membrane proteins by 2D-DIGE and tandem mass spectrometry. Exp Biol Med 2005, 230(11):787-792

21. Houslay MD, Kolch W: Cell-type specific integration of cross-talk between extracellular signal-regulated kinase and cAMP signaling. Mol Pharmacol 2000, 58(4):659-668.

22. Kolch W: Meaningful relationships: the regulation of the Ras/Raf/MEK/ ERK pathway by protein interactions. Biochem J 2000, 351(Pt 2):289-305.

23. O'Connell S, Tuite N, Slattery C, Ryan MP, McMorrow T: Cyclosporine ainduced oxidative stress in human renal mesangial cells: a role for ERK 1/2 MAPK signalling. Toxicol Sci 2012, 126(1):101-113.

24. Gesty-Palmer D, Chen M, Reiter E, Ahn S, Nelson CD, Wang S, Eckhardt AE, Cowan CL, Spurney RF, Luttrell LM, et al: Distinct beta-arrestin- and G protein-dependent pathways for parathyroid hormone receptorstimulated ERK1/2 activation. J Biol Chem 2006, 281(16):10856-10864.

25. Numata T, Araya J, Fujii S, Hara H, Takasaka N, Kojima J, Minagawa S, Yumino Y, Kawaishi M, Hirano J, et al: Insulin-dependent phosphatidylinositol 3-kinase/Akt and ERK signaling pathways inhibit TLR3-mediated human bronchial epithelial cell apoptosis. J Immunol 2011, 187(1):510-519.

26. Hu LA, Chen W, Martin NP, Whalen EJ, Premont RT, Lefkowitz RJ: GIPC interacts with the beta1-adrenergic receptor and regulates beta 1-adrenergic receptor-mediated ERK activation. J Biol Chem 2003, 278(28):26295-26301.

27. Pratsinis H, Constantinou V, Pavlakis K, Sapkas G, Kletsas D: Exogenous and autocrine growth factors stimulate human intervertebral disc cell proliferation via the ERK and Akt pathways. J Orthop Res 2012, Jun 30(6):958-964.

28. Cheung EC, Slack RS: Emerging role for ERK as a key regulator of neuronal apoptosis. Sci STKE 2004, 2004(251):PE45.

29. Fincham VJ, James M, Frame MC, Winder SJ: Active ERK/MAP kinase is targeted to newly forming cell-matrix adhesions by integrin engagement and v-Src. EMBO J 2000, 19(12):2911-2923.

30. Joslin EJ, Opresko LK, Wells A, Wiley HS, Lauffenburger DA: EGF-receptormediated mammary epithelial cell migration is driven by sustained ERK signaling from autocrine stimulation. J Cell Sci 2007,

120(Pt 20):3688-3699.
31. Park KS, Jeon SH, Kim SE, Bahk YY, Holmen SL, Williams BO, Chung KC, Surh YJ, Choi KY: APC inhibits ERK pathway activation and cellular proliferation induced by RAS. J Cell Sci 2006, 119(Pt 5):819-827.

32. Cai K, Qi D, Hou X, Wang O, Chen J, Deng B, Qian L, Liu X, Le Y: MCPupregulates amylin expression in murine pancreatic beta cells through ERK/JNK-AP1 and NF-kappaB related signaling pathways independent of CCR2. PLoS One 2011, 6(5):e19559.

33. Wang N, Guan P, Zhang JP, Li YQ, Chang YZ, Shi ZH, Wang FY, Chu L: Fasudil hydrochloride hydrate, a Rho-kinase inhibitor, suppresses isoproterenol-induced heart failure in rats via JNK and ERK1/2 pathways. J Cell Biochem 2011, 112(7):1920-1929.

34. Soderblom EJ, Philipp M, Thompson JW, Caron MG, Moseley MA: Quantitative label-free phosphoproteomics strategy for multifaceted experimental designs. Anal Chem 2011, 83(10):3758-3764.

35. De Franceschi L, Biondani A, Carta F, Turrini F, Laudanna C, Deana R, Brunati AM, Turretta L, Iolascon A, Perrotta S, et al: PTPepsilon has a critical role in signaling transduction pathways and phosphoprotein network topology in red cells. Proteomics 2008, 8(22):4695-4708.

36. Beausoleil SA, Villen J, Gerber SA, Rush J, Gygi SP: A probability-based approach for high-throughput protein phosphorylation analysis and site localization. Nature Biotech 2006, 24(10):1285-1292.

37. Rochais F, Vandecasteele G, Lefebvre F, Lugnier C, Lum H, Mazet JL, Cooper DM, Fischmeister R: Negative feedback exerted by cAMPdependent protein kinase and CAMP phosphodiesterase on subsarcolemmal CAMP signals in intact cardiac myocytes: an in vivo study using adenovirus-mediated expression of CNG channels. J Biol Chem 2004 279(50):52095-52105.

38. Anong WA, Franco T, Chu H, Weis TL, Devlin EE, Bodine DM, An X, Mohandas N, Low PS: Adducin forms a bridge between the erythrocyte membrane and its cytoskeleton and regulates membrane cohesion. Blood 2009, 114(9):1904-1912

39. Marikovsky Y, Danon D: Electron microscope analysis of young and old red blood cells stained with colloidal iron for surface charge evaluation J Cell Biol 1969, 43(1):1-7.

40. Husain-Chishti A, Levin A, Branton D: Abolition of actin-bundling by phosphorylation of human erythrocyte protein 4.9. Nature 1988, 334 (6184):718-721.

41. Siegel DL, Branton D: Partial purification and characterization of an actin-bundling protein, band 4.9, From human erythrocytes. J Cell Biol 1985, 100(3):775-785.

42. Jiang ZG, McKnight CJ: A phosphorylation-induced conformation change in dematin headpiece. Structure 2006, 14(2):379-387.

43. Khanna R, Chang SH, Andrabi S, Azam M, Kim A, Rivera A, Brugnara C, Low PS, Liu SC, Chishti AH: Headpiece domain of dematin is required for the stability of the erythrocyte membrane. Proc Natl Acad Sci U S A 2002, 99(10):6637-6642

44. Harris HW Jr, Lux SE: Structural characterization of the phosphorylation sites of human erythrocyte spectrin. J Biol Chem 1980, 255(23):11512-11520.

45. Boivin P, Garbarz M, Dhermy D, Galand C: In vitro phosphorylation of the red blood cell cytoskeleton complex by cyclic AMP-dependent protein kinase from erythrocyte membrane. Bioch Biophys acta 1981, 647(1):1-6.

46. Avruch J, Fairbanks G: Phosphorylation of endogenous substrates by erythrocyte membrane protein kinases I. A monovalent cationstimulated reaction. Biochem 1974, 13(27):5507-5514.

47. Hosey MM, Tao M: Phosphorylation of rabbit and human erythrocyte membranes by soluble adenosine 3':5'-monophosphate-dependent and -independent protein kinases. J Biol Chem 1977, 252(1):102-109.

48. Wolfe LC, Lux SE: Membrane protein phosphorylation of intact normal and hereditary spherocytic erythrocytes. J Biol Chem 1978, 253(9):3336-3342.

49. Manno S, Takakuwa Y, Nagao K, Mohandas N: Modulation of erythrocyte membrane mechanical function by beta-spectrin phosphorylation and dephosphorylation. J Biol Chem 1995, 270(10):5659-5665

50. Gu Z, Liu W, Wei J, Yan Z: Regulation of N-methyl-D-aspartic acid (NMDA) receptors by metabotropic glutamate receptor 7. J Biol Chem 2012, 287(13):10265-10275.

51. Forsythe ID, Clements JD: Presynaptic glutamate receptors depress excitatory monosynaptic transmission between mouse hippocampal neurones. J Physiol 1990, 429:1-16. 
52. Gereau RW, Conn PJ: Multiple presynaptic metabotropic glutamate receptors modulate excitatory and inhibitory synaptic transmission in hippocampal area CA1. J Neurosc 1995, 15(10):6879-6889.

53. Herrero I, Sanchez-Prieto J: CAMP-dependent facilitation of glutamate release by beta-adrenergic receptors in cerebrocortical nerve terminals. J Biol Chem 1996, 271(48):30554-30560.

54. Martin R, Bartolome-Martin D, Torres M, Sanchez-Prieto J: Non-additive potentiation of glutamate release by phorbol esters and metabotropic mGlu7 receptor in cerebrocortical nerve terminals. J Neurochem 2011, 116(4):476-485.

55. Hubberstey AV, Mottillo EP: Cyclase-associated proteins: CAPacity for linking signal transduction and actin polymerization. FASEB J 2002 , 16(6):487-499.

56. Bertling E, Hotulainen P, Mattila PK, Matilainen T, Salminen M, Lappalainen P: Cyclase-associated protein 1 (CAP1) promotes cofilin-induced actin dynamics in mammalian nonmuscle cells. Mol Biol Cell 2004, 15(5):2324-2334

57. Marchesi VT, Tillack TW, Jackson RL, Segrest JP, Scott RE: Chemical characterization and surface orientation of the major glycoprotein of the human erythrocyte membrane. Proc Natl Acad Sci U S A 1972, 69(6):1445-1449.

58. Furthmayr $\mathrm{H}$, Marchesi VT: Subunit structure of human erythrocyte glycophorin a. Biochem 1976, 15(5):1137-1144.

59. Shapiro DL, Marchesi VT: Phosphorylation in membranes of intact human erythrocytes. J Biol Chem 1977, 252(2):508-517.

60. Zennadi R, Hines PC, De Castro LM, Cartron JP, Parise LV, Telen MJ: Epinephrine acts through erythroid signaling pathways to activate sickle cell adhesion to endothelium via LW-alphavbeta3 interactions. Blood 2004, 104(12):3774-3781.

61. Crews CM, Alessandrini A, Erikson RL: Erks: their fifteen minutes has arrived. Cell Growth Differ 1992, 3(2):135-142.

62. Yu YQ, Gilar M, Lee PJ, Bouvier ES, Gebler JC: Enzyme-friendly, mass spectrometry-compatible surfactant for in-solution enzymatic digestion of proteins. Anal Chem 2003, 75(21):6023-6028.

63. Brunati AM, Bordin L, Clari G, James P, Quadroni M, Baritono E, Pinna LA, Donella-Deana A: Sequential phosphorylation of protein band 3 by Syk and Lyn tyrosine kinases in intact human erythrocytes: identification of primary and secondary phosphorylation sites. Blood 2000, 96(4):1550-1557.

64. Weng L, Dai H, Zhan Y, He Y, Stepaniants SB, Bassett DE: Rosetta error model for gene expression analysis. Bioinformatics 2006, 22(9):1111-1121.

doi:10.1186/1559-0275-10-1

Cite this article as: Soderblom et al:: Proteomic analysis of ERK1/2mediated human sickle red blood cell membrane protein phosphorylation. Clinical Proteomics 2013 10:1.

\section{Submit your next manuscript to BioMed Central and take full advantage of:}

- Convenient online submission

- Thorough peer review

- No space constraints or color figure charges

- Immediate publication on acceptance

- Inclusion in PubMed, CAS, Scopus and Google Scholar

- Research which is freely available for redistribution 